\title{
Effective Interventions for Improving Functional Movement Screen Scores Among “High-Risk” Athletes: A Systematic Review
}

\author{
Sean C. Clark, MS ${ }^{1}$ (D) ${ }^{\text {, }}$ Nicholas D. Rowe, BA ${ }^{1}$, Mohamed Adnan, BA ${ }^{1}$, Symone M. Brown, MPH², Mary K. Mulcahey, MD \\ 1 Tulane University School of Medicine, ${ }^{2}$ Department of Orthopaedic Surgery, Tulane University School of Medicine \\ Keywords: intervention program, injury prevention, injury risk reduction, functional movement screen, movement system \\ https://doi.org/10.26603/001c.31001
}

\section{International Journal of Sports Physical Therapy}

Vol. 17, Issue 2, 2022

\section{Background}

The Functional Movement Screen ${ }^{\mathrm{TM}}\left(\mathrm{FMS}^{\mathrm{TM}}\right)$ is a tool designed to screen a series of movements that aids in the identification of compensatory fundamental movement patterns, functional limitations, and asymmetrical movement patterns. A previous systematic review and meta-analysis has shown that athletes with an FMS ${ }^{\mathrm{TM}}$ score $<13-14$ are considered "high-risk" and are more likely to be injured. There are discrepancies regarding the efficacy of physical intervention programs in improving FMS ${ }^{\mathrm{TM}}$ scores.

\section{Purpose}

The aim of this systematic review was to assess the role of physical intervention programs in increasing functional movement in "high-risk" athletes as measured by the FMS ${ }^{\mathrm{TM}}$.

\section{Study Design}

Systematic Review

\section{Methods}

A computerized search was performed in 2019 according to PRISMA guidelines searching Embase, Science Direct, Ovid, and PubMed. The studies were assessed for quality and risk of bias using the Modified Downs and Black checklist. Participant demographics, intervention routines, and FMS ${ }^{\mathrm{TM}}$ scores were extracted from the included studies.

\section{Results}

Six studies met the inclusion criteria and demonstrated a fair methodological quality. Comparisons across all studies revealed significant improvement in $\mathrm{FMS}^{\mathrm{TM}}$ scores following implementation of a variety of physical intervention programs. These programs included those that utilized functional training, foot muscle strengthening, Pilates, core stability training, and resistance movements. Despite variations in the corrective exercises performed, the number of training sessions, and the length of the intervention program, all studies demonstrated an increase in the total $\mathrm{FMS}^{\mathrm{TM}}$ score following program implementation.

\section{Conclusion}

The included intervention programs significantly improved total FMS ${ }^{\mathrm{TM}}$ scores in "high-risk" athletes. Despite variations in the corrective exercises (interventions) performed, the number of training sessions, and the length of the program, all studies demonstrated a significant increase in the total FMS ${ }^{\mathrm{TM}}$ score following program

\footnotetext{
a Corresponding Author: 
implementation.

\section{INTRODUCTION}

The Functional Movement Screen ${ }^{\mathrm{TM}}\left(\mathrm{FMS}^{\mathrm{TM}}\right)$ is a tool designed to screen a series of movements that aids in the identification of compensatory fundamental movement patterns, functional limitations, and asymmetrical movement patterns. ${ }^{1,2}$ The FMS ${ }^{\mathrm{TM}}$ includes seven screening tests: active straight leg raise, deep squat, hurdle step, inline lunge, rotary stability, shoulder mobility, and trunk stability push-up. With a maximum total FMS ${ }^{\mathrm{TM}}$ score of 21 points, each test is rated on a three-point scale ranging from zero (pain during the action) to three (correctly performed action).

Athletic injuries hamper the ability of athletes to compete at all levels. Sheu et al. estimates that 8.6 million sports and recreation related injuries occur each year in the United States, translating into 34.1 injuries per 1000 people. ${ }^{3}$ The development and execution of preventative exercise programs could reduce the severity and occurrence of athletic injuries. ${ }^{4}$

The FMS ${ }^{\mathrm{TM}}$ has become a popular tool to identify athletes with a higher likelihood of developing a sports related injury. ${ }^{5}$ Kiesel et al., noted that athletes with total FMS ${ }^{\mathrm{TM}}$ scores $\leqslant 14$ had an 11 times increased risk of serious injury and a $51 \%$ probability of sustaining a serious injury over the course of one competitive season. ${ }^{6}$ Since the FMS ${ }^{\mathrm{TM}}$ has been proposed to identify muscular imbalance, interventional prophylactic strengthening programs targeting muscular imbalances can be implemented..$^{5}$ Identifying "highrisk" athletes in pre-season screening with a low cost, time efficient, and low physical risk screening tool could decrease medical costs, the number of serious injuries, and time lost to injury. ${ }^{7}$ The FMS $^{\mathrm{TM}}$ may provide coaches, athletic trainers, physical therapists, and other healthcare providers with valuable information needed for early detection of injury-prone athletes who may benefit from intervention. After determining that an athlete could be at risk for injury (FMS ${ }^{\mathrm{TM}}$ score $\leqslant 14$ ), a six-to-eight-week long intervention program consisting of corrective exercises aimed at improving functional movements could be implemented. 5,8,9 Recently, authors have demonstrated that incorporating an intervention program can improve symmetry, ${ }^{8}$ core strength, ${ }^{10}$ flexibility, ${ }^{11}$ and general strength, ${ }^{11}$ all of which help reduce the risk of injury. A systematic review and meta-analysis by Bunn et al. demonstrated that those defined as having a "high-risk" FMS ${ }^{\mathrm{TM}}$ score $(<13-14)$ were $51 \%$ more likely to be injured than individuals with FMS $^{\mathrm{TM}}$ scores $>14 .{ }^{12}$ The aim of this systematic review was to assess the role of physical intervention programs in increasing functional movement in "high-risk" athletes as measured by the FMS ${ }^{\mathrm{TM}}$.

\section{METHODS}

This study was performed according to the Preferred Reporting Items for Systematic Reviews and Meta-Analyses (PRISMA) guidelines and was prospectively registered with PROSPERO (121423). ${ }^{13}$
INFORMATION SOURCES, ELIGIBILITY CRITERIA, AND STUDY SELECTION

Articles were identified by searching Embase, Science Direct, Ovid, and PubMed using the following terms: "Functional Movement Screen" AND "Intervention” AND "Functional Movement Screen" AND “Training." In addition to searching these databases, the reference lists of identified studies were evaluated to find other articles that met the inclusion criteria. After duplicates were removed, the titles and abstracts for all remaining studies were then screened by two authors (S.C.C \& N.D.R) and consensus was achieved. Full-text articles were obtained for further assessment of inclusion and exclusion criteria by two authors (S.C.C \& N.D.R). Studies were included if they met the following criteria: (1) written in English; (2) observational prospective cohort design; (3) reported original and peerreviewed data; (4) composite FMS $^{\mathrm{TM}}$ score was used to define exposure and non-exposure groups; (5) an intervention program was implemented after FMS ${ }^{\mathrm{TM}}$ screening; (6) population included athletes. Exclusion criteria included: (1) data reported in conference abstracts, reviews, case reports, technique articles, theses or non-peer-reviewed literature; (2) studies employing cross-sectional or retrospective study designs; (3) intervention programs that were not standardized and could not be replicated.

\section{DATA COLLECTION}

All of the included studies were critically appraised for reporting quality, external validity, internal validity bias, internal validity confounding and power using the Modified Downs and Black checklist. ${ }^{14}$ The level of evidence of each qualified study was assigned according to classifications specified by Wright et al. (Level 1 - Level 5). ${ }^{15}$ The following information was collected from the included studies: participant demographics, intervention routines and FMS ${ }^{\mathrm{TM}}$ scores. This information was collected manually by one author and checked for reliability and errors by a second author. For continuous variables (e.g., age, intervention time, FMS $^{\mathrm{TM}}$ scores), the mean and range were collected, if reported. The included studies obtained informed consent and the rights of the subjects were protected.

Given the heterogeneity of the sports studied and the interventional and methodological variability present across studies, meta-analysis of pooled results was not performed. Rather, an objective analysis was performed to evaluate the potential effectiveness of proposed intervention programs.

\section{RESULTS}

The literature searches identified 361 potential studies. After the removal of 118 duplicates and 172 studies that did not meet inclusion criteria, 71 articles were available for full-text review. Following thorough review of these articles and their references, a total of six studies were included in this study (Figure 1).

Six studies with a total of 256 patients were analyzed. Three of the included studies (50\%) were Level 2 evidence, 
Table 1. Modified Downs and Black scores for included studies

\begin{tabular}{|c|c|c|c|c|c|c|}
\hline Study & Reporting & External Validity & Bias & Confounding & Power & Total \\
\hline Bagherian et al. ${ }^{16}$ & 9 & 1 & 4 & 2 & 1 & 17 \\
\hline Bodden et al. ${ }^{17}$ & 9 & 1 & 5 & 1 & 1 & 17 \\
\hline Kluseman et al. ${ }^{18}$ & 8 & 1 & 5 & 2 & 0 & 16 \\
\hline Laws et al. ${ }^{19}$ & 9 & 1 & 5 & 2 & 1 & 18 \\
\hline Sulowska et al. ${ }^{20}$ & 9 & 1 & 5 & 2 & 1 & 18 \\
\hline Yildiz et al. ${ }^{21}$ & 8 & 1 & 5 & 1 & 1 & 16 \\
\hline
\end{tabular}
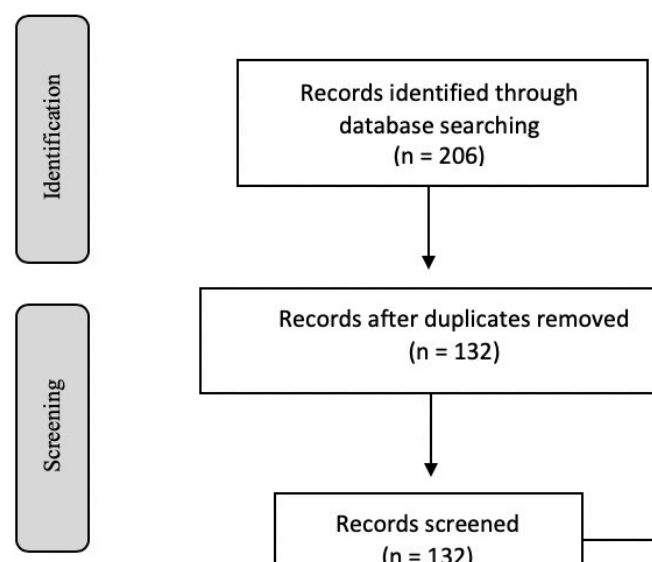

Records after duplicates removed $(n=132)$
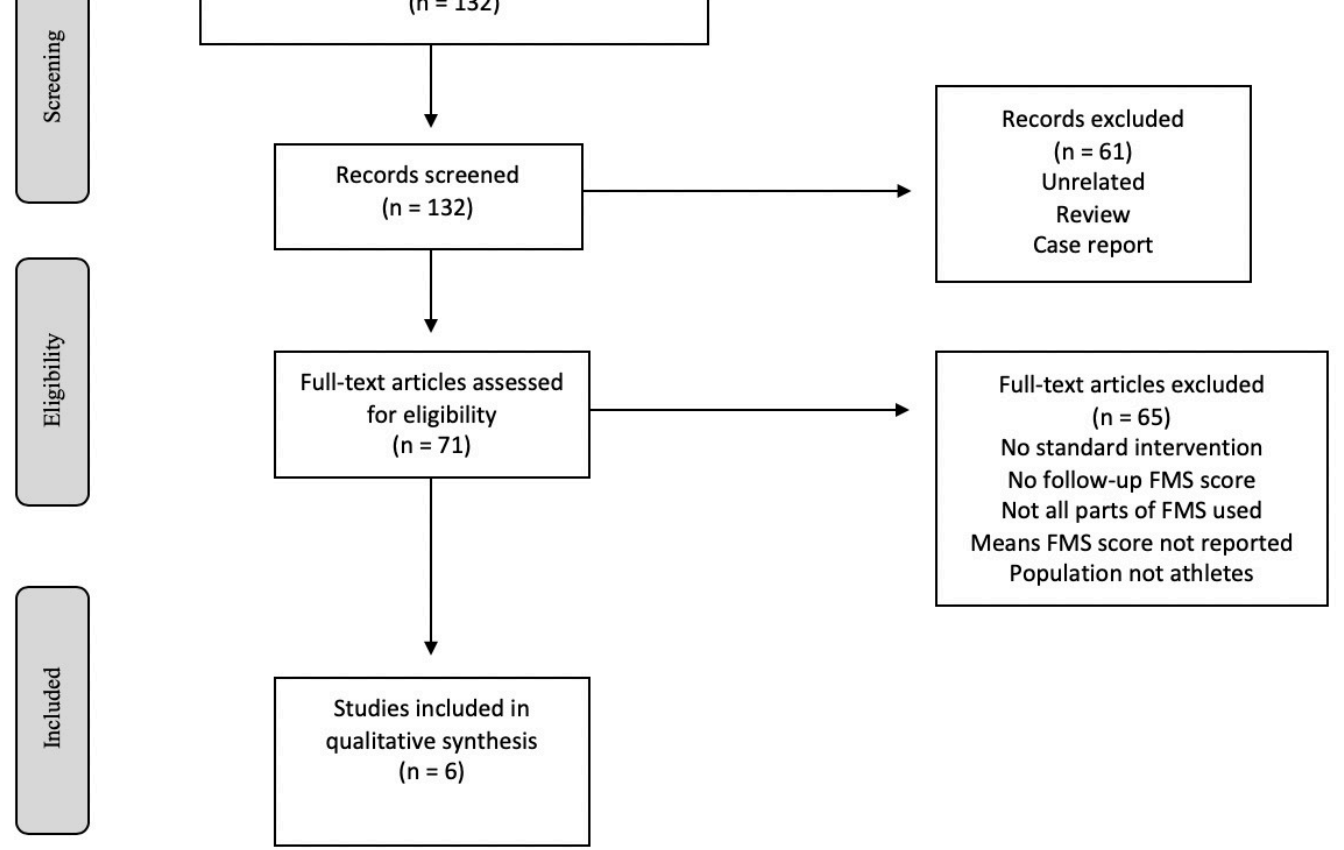

Figure 1. Flow diagram summarizing the literature search, screening, and review.

while the remaining three were Level 3 . The studies included demonstrated a fair methodological quality, with a range of $16-18$ (Table 1 ). The majority of patients were males $(\mathrm{n}=184)$, although two studies included females ( $\mathrm{n}$ $=32$ ) and one study did not provide participant gender $(\mathrm{n}=$ $40)$. Athletes played a variety of sports including basketball $(\mathrm{n}=78)$, futsal $(\mathrm{n}=40)$, mixed martial arts $(\mathrm{n}=33)$, running $(n=65)$, tennis $(n=28)$ and volleyball $(n=12)$. The level of sport included 66 youth participants (25.8\%), 65 recreational level participants (25.4\%), 100 collegiate athletes (39.1\%) and 25 semi-professional athletes (9.8\%) (Table 2).

All six studies provided a mean pre-intervention $\mathrm{FMS}^{\mathrm{TM}}$ score, which ranged from 11.8 to 14.4 (Table 3). Length of intervention varied between studies, with a range of six to eight weeks. Post-intervention FMS $^{\mathrm{TM}}$ scores were reported in all studies and significantly increased, with a range of 14.8 to 19.3 (p-values 0.001 - 0.017). The mean improvement in FMS $^{\mathrm{TM}}$ scores following an intervention program across all studies was 3.28 points. FMS ${ }^{\mathrm{TM}}$ score improvement ranged from 2.09 to 5.3 points following an intervention program.

Intervention programs included core stability training, clinical Pilates, resistance training, functional training, and foot muscle strengthening exercises (Table 4). Each pro- 
Table 2. Summary of included studied and patient demographics

\begin{tabular}{|c|c|c|c|c|c|c|c|}
\hline Study & Year & LOE & $\mathrm{n}$ & $\begin{array}{c}\text { Age } \\
(\text { Mean } \pm S D)\end{array}$ & Gender & Sport & Level \\
\hline $\begin{array}{l}\text { Bagherian } \\
\text { et al. }{ }^{16}\end{array}$ & 2018 & 3 & 100 & $18.1 \pm 0.9$ & Male & $\begin{array}{l}\text { Basketball }(n=40), \text { futsal } \\
(n=40) \text {, volleyball }(n=12), \\
\text { mixed martial arts }(n=8)\end{array}$ & Collegiate \\
\hline $\begin{array}{l}\text { Bodden } \\
\text { et al. }{ }^{17}\end{array}$ & 2015 & 2 & 25 & $24.31 \pm 4.46$ & Male & Mixed martial arts & $\begin{array}{c}\text { Semi- } \\
\text { professional }\end{array}$ \\
\hline $\begin{array}{l}\text { Kluseman } \\
\text { et al. }{ }^{18}\end{array}$ & 2012 & 3 & 38 & $14.5 \pm 1$ & $\begin{array}{l}\text { Male } \\
(n=17) \\
\text { Female } \\
(n=21)\end{array}$ & Basketball & Youth \\
\hline $\begin{array}{l}\text { Laws et } \\
\text { al. }^{19}\end{array}$ & 2017 & 2 & 40 & $\begin{array}{l}\text { Not } \\
\text { reported }\end{array}$ & $\begin{array}{c}\text { Not } \\
\text { reported }\end{array}$ & Runners & Recreational \\
\hline $\begin{array}{l}\text { Sulowska } \\
\text { et al. }{ }^{20}\end{array}$ & 2016 & 2 & 25 & $28 \pm 3.86$ & $\begin{array}{l}\text { Male } \\
(n=14) \\
\text { Female } \\
(n=11)\end{array}$ & Runners & Recreational \\
\hline $\begin{array}{c}\text { Yildiz et } \\
\text { al. }^{21}\end{array}$ & 2019 & 3 & 28 & $9.6 \pm 0.7$ & Male & Tennis & Youth \\
\hline
\end{tabular}

LOE $=$ Level of Evidence

Table 3. FMS ${ }^{\mathrm{TM}}$ data

\begin{tabular}{|c|c|c|c|c|c|c|c|}
\hline Study & Year & $\mathrm{n}$ & $\begin{array}{c}\text { Length of } \\
\text { Intervention } \\
\text { (weeks) }\end{array}$ & $\begin{array}{c}\text { Baseline } \\
\text { FMS } \\
\text { (Mean } \pm \text { SD }\end{array}$ & $\begin{array}{c}\text { Post- } \\
\text { intervention } \\
\text { FMS } \\
\text { (Mean } \pm \text { SD }\end{array}$ & p-value & $\begin{array}{c}\text { Average } \\
\text { FMS } \\
\text { Increase }\end{array}$ \\
\hline $\begin{array}{c}\text { Bagherian } \\
\text { et al. }{ }^{16}\end{array}$ & 2018 & 100 & 8 & $14.4 \pm 2.02$ & $17.8 \pm 1.7$ & 0.001 & 3.4 \\
\hline $\begin{array}{c}\text { Bodden } \\
\text { et al. }{ }^{17}\end{array}$ & 2015 & 25 & 8 & $13.25 \pm 0.87$ & $15.17 \pm 1.21$ & 0.006 & 2.08 \\
\hline $\begin{array}{c}\text { Kluseman } \\
\text { et al. }{ }^{18 a}\end{array}$ & 2012 & 38 & 6 & $14 \pm 1$ & $16 \pm 2$ & $<0.05$ & 2 \\
\hline $\begin{array}{c}\text { Laws et } \\
\text { al. }{ }^{19}\end{array}$ & 2017 & 40 & 6 & $13.4 \pm 2.4$ & $17.0 \pm 1.96$ & $<0.01$ & 3.6 \\
\hline $\begin{array}{c}\text { Sulowska } \\
\text { et al. }{ }^{20 b}\end{array}$ & 2016 & 25 & 6 & $13 \pm 4.91$ & $17 \pm 1.96$ & 0.002 & 4 \\
\hline $\begin{array}{c}\text { Yildiz et } \\
\text { al. }{ }^{21 c}\end{array}$ & 2019 & 28 & 8 & $14.0 \pm 1.8$ & $19.3 \pm 0.8$ & 0.017 & 5.3 \\
\hline
\end{tabular}

a)Klusemann, two intervention groups in study, data provided for supervised group

b)Sulowska, two intervention groups in study, data provided for group 1

c)Yildiz, two intervention groups in study, data provided for functional training group

grams had their own unique set of exercises, some examples included the front plank, squats, and a medicine ball throw.

\section{DISCUSSION}

The main finding of this systematic review was that despite variations in the corrective exercises performed, the number of training sessions, and the length of the intervention program, all studies demonstrated a significant increase in the total FMS $^{\mathrm{TM}}$ score following program implementation
(Table 3). These programs included those that utilized functional training, foot muscle strengthening, Pilates, core stability training, and resistance movements.

Bagherian et al. evaluated FMS ${ }^{\mathrm{TM}}$ scores following an intervention program focused on improving core strength in 100 male collegiate athletes participating in various sports. ${ }^{16}$ This eight-week core stability training program increased the total FMS ${ }^{\mathrm{TM}}$ scores among athletes by $3.4 \pm 1.7$ points on average $(p=0.001)$. These authors also noted that there total FMS ${ }^{\mathrm{TM}}$ score improvement was dependent upon 
Table 4. Comparison of included studies

\begin{tabular}{|c|c|c|c|}
\hline Study & Intervention & Corrective Movements & Main Findings \\
\hline $\begin{array}{l}\text { Bagherian } \\
\text { et al. }{ }^{16}\end{array}$ & $\begin{array}{l}\text { Core stability } \\
\text { training } \\
\text { program, } 3 \\
\text { times per } \\
\text { week for } 8 \\
\text { weeks }\end{array}$ & $\begin{array}{l}\text { Front plank, back bridge, side bridge, sit ups, } \\
\text { back extensions, lateral step down, Y-balance } \\
\text { test }\end{array}$ & $\begin{array}{c}\text { Increase in total FMS } \mathrm{FM}^{\mathrm{TM}} \text { scores by } 3.4 \\
\text { points on average. The baseline FMS }{ }^{\mathrm{TM}} \\
\text { scores }>14 \text { increased by } 2.4 \text { points on } \\
\text { average }\end{array}$ \\
\hline $\begin{array}{l}\text { Bodden } \\
\text { et al. }{ }^{17}\end{array}$ & $\begin{array}{l}\text { Resistance } \\
\text { training } \\
\text { movements, } 4 \\
\text { times per } \\
\text { week for } 8 \\
\text { weeks } \\
\end{array}$ & $\begin{array}{l}\text { Half-kneeling chops, kettlebell halos tall- } \\
\text { kneeling chops, half get-ups, deadlifts, single- } \\
\text { leg opposite-arm deadlifts, bottom-up } \\
\text { kettlebell cleans, squats, overhead press }\end{array}$ & $\begin{array}{c}\text { Increase in total FMS } \mathrm{TM}^{\mathrm{TM}} \text { scores by } 2.08 \\
\text { points on average. Limited difference } \\
\text { between average FMS } \mathrm{S}^{\mathrm{TM}} \text { scores at week } 4 \\
\text { (1.92) and week } 8(2.08)\end{array}$ \\
\hline $\begin{array}{l}\text { Kluseman } \\
\text { et al. }{ }^{18}\end{array}$ & $\begin{array}{l}\text { Resistance } \\
\text { training } \\
\text { movements, } 2 \\
\text { times per } \\
\text { week for } 6 \\
\text { weeks }\end{array}$ & $\begin{array}{c}\text { Speed (20m sprint), vertical jump, line drill } \\
\text { test, aerobic capacity countermovement, jump } \\
\text { height, overhead squat, hurdle step, in-line } \\
\text { lunge, shoulder mobility, straight leg raises, } \\
\text { push up }\end{array}$ & $\begin{array}{l}\text { Increase in total FMS } \mathrm{FM}^{\mathrm{TM}} \text { scores by } 2 \text { points } \\
\text { on average. The supervised group is the } \\
\text { only group to experience a deviation from } \\
\text { baseline in } \mathrm{FMS}^{\mathrm{TM}} \text { score calculations. }\end{array}$ \\
\hline $\begin{array}{l}\text { Laws et } \\
\text { al. }{ }^{19}\end{array}$ & $\begin{array}{l}\text { Clinical } \\
\text { Pilates } \\
\text { regimen, } 1 \\
\text { time per } \\
\text { week for } 6 \\
\text { weeks }\end{array}$ & $\begin{array}{l}\text { Hip twists, single leg stretches, double leg } \\
\text { stretches, clams, shoulders bridges, scissors, } \\
\text { arm openings, breast strokes }\end{array}$ & $\begin{array}{l}\text { Increase in total } \mathrm{FMS}^{\mathrm{TM}} \text { scores by } 3.5 \\
\text { points on average }\end{array}$ \\
\hline $\begin{array}{l}\text { Sulowska } \\
\text { et al. }{ }^{20}\end{array}$ & $\begin{array}{l}\text { Foot muscle } \\
\text { strengthening } \\
\text { exercises, } 7 \\
\text { times per } \\
\text { week for } 6 \\
\text { weeks }\end{array}$ & $\begin{array}{l}\text { Vele's forward lean exercise and reverse } \\
\text { tandem gait (group 1). Short-foot exercise } \\
\text { (group 2). }\end{array}$ & $\begin{array}{l}\text { Increase in total FMS }{ }^{\mathrm{TM}} \text { score by } 4 \text { points } \\
\text { on average in group } 2 . \text { Group 2's results } \\
\text { were not statistically significant. }\end{array}$ \\
\hline $\begin{array}{l}\text { Yildiz et } \\
\text { al. }^{21}\end{array}$ & $\begin{array}{l}\text { Functional } \\
\text { training, } 3 \\
\text { times per } \\
\text { week for } 8 \\
\quad \text { weeks }\end{array}$ & $\begin{array}{l}\text { Squat, dead bug, climbing man, plank, bridge, } \\
\text { chop, lift, push up, pull up, medicine ball throw }\end{array}$ & $\begin{array}{c}\text { Increase in total FMS } \mathrm{FM}^{\mathrm{TM}} \text { scores by } 5.3 \\
\text { points on average. Participants in the } \\
\text { traditional training group experienced a } \\
\text { decrease in FMS } \mathrm{FM}^{\mathrm{TM}} \text { scores by an average } \\
\text { of } 1.6 \text { points. }\end{array}$ \\
\hline
\end{tabular}

the participant's baseline FMS ${ }^{\mathrm{TM}}$ score. Those with a baseline FMS ${ }^{\mathrm{TM}}$ total score $<14$ improved by $4.4 \pm 2.3$ points on average, while those with a baseline FMS ${ }^{\mathrm{TM}}$ total score $>14$ only improved by $2.4 \pm 1.8$ points on average. ${ }^{16}$ This may have been due to a ceiling effect as there is less potential for improvement for those with a baseline FMS $^{\mathrm{TM}}$ total score $>14$. Core stability and neuromuscular control are important intrinsic factors that can impact an athlete's risk of injury. ${ }^{22,23}$

Bodden et al. evaluated FMS ${ }^{\mathrm{TM}}$ scores following an intervention program that focused on resistance training in semiprofessional mixed martial arts (MMA) athletes. ${ }^{17}$ Their eight-week program increased the total $\mathrm{FMS}^{\mathrm{TM}}$ scores among athletes by $2.08 \pm 1.21$ points on average $(p=0.006)$. In addition to calculating an $\mathrm{FMS}^{\mathrm{TM}}$ score at the completion of the intervention program, the authors calculated a score mid-way through the program. There was an increase in $\mathrm{FMS}^{\mathrm{TM}}$ scores of 1.92 points between week zero and week four ( $p=0.00$ ); however, between weeks four and eight, the scores only increased by 0.16 points $(p=1.00)$. This may indicate that the duration of intervention programs could be examined, and shortening a program to four weeks be considered.
Laws et al. evaluated FMS ${ }^{\mathrm{TM}}$ scores following an intervention program that focused on Clinical Pilates, specifically the Australian Physiotherapy \& Pilates Institute (APPI) Clinical Pilates method, in recreational runners. ${ }^{19}$ The underlying concept of Pilates is that compensatory movements, muscle imbalance, and poor habitual patterns of movement are the leading causes of injury and could be avoided through core strengthening. ${ }^{24}$ Clinical Pilates focuses on developing the core proximal stability muscles, which contribute to normal movement control. ${ }^{24,25}$ This six-week Clinical Pilates program increased total FMS scores by $3.5 \pm 1.7$ points on average $(p<0.01)$. These findings support the concept that improving functional movement control through core strengthening can potentially reduce the risk of injury. ${ }^{19}$

Klusemann et al. evaluated FMS ${ }^{\mathrm{TM}}$ scores following an intervention program that focused on resistance training movements in youth basketball players. ${ }^{18}$ In this study, participants were placed into two intervention groups that performed the same regimen; a fully supervised group and an online instructional video-based group. The six-week supervised resistance training program raised total FMS ${ }^{\mathrm{TM}}$ scores by $2 \pm 2$ points on average $(p<0.05)$. The online in- 
structional video-based group did not demonstrate an increase in total $\mathrm{FMS}^{\mathrm{TM}}$ scores despite performing the same routine as the supervised group. Participant lack of compliance with the prescribed regimen or improper execution may be responsible for this variation. Supervised training appears to be the more effective method of program delivery. 18

Sulowska et al. evaluated FMS ${ }^{\mathrm{TM}}$ scores following an intervention program focused on improving foot muscle strength in long distance runners. ${ }^{20}$ In this study, participants were placed into two intervention groups with Group 1 performing Vele's forward lean exercise (feet separated at shoulder distance and flat on ground while leaning upper body forward) and reverse tandem gait (walking heel-totoe backwards), while Group 2 performed short-foot exercise (pulling the head of first metatarsal toward the calcaneus without curling the toes). Group 1 had an increase in total FMS ${ }^{\mathrm{TM}}$ score of $4 \pm 1.96$ points on average $(\mathrm{p}=0.002)$. Group 2 had an increase in total FMS ${ }^{\mathrm{TM}}$ score of $2 \pm 2.4$ points on average, but the results were not statistically significant $(p=0.063)$. Some studies have examined the relationship between increased risk of acute injury or repetitive strain injury and excessive foot pronation. ${ }^{26,27}$ It has been reported that individuals with flat-arched feet have more prominent pronation in stance than high-arched individuals. $^{28}$ The authors assessed foot posture using the Foot Posture Index (FPI-6) and noticed a change towards the neutral foot. ${ }^{20}$ Specifically, Group 1 had a significant improvement in talar head palpation, while Group 2 had a significant improvement in inversion/eversion of the calcaneus. The higher total score in the FMS ${ }^{\mathrm{TM}}$ test indicates that the applied exercises may improve the quality of overall movement patterns. ${ }^{20}$

Yildiz et al. evaluated FMS ${ }^{\mathrm{TM}}$ scores following an intervention program in youth tennis players that focused either on functional training (consisting of movements that improved mobility and utilized the kinetic chain), or traditional training, which involved single-joint movements and a focus on local muscle groups. ${ }^{21}$ This eight-week functional training intervention program increased total Group $1 \mathrm{FMS}^{\mathrm{TM}}$ scores by 5.3 points on average $(\mathrm{p}<0.01)$ while traditional training decreased total Group 2 FMS $^{\mathrm{TM}}$ scores by an average of 1.6 points ( $p<0.01$ ). Functional training is a form of training whereby a target movement is performed rather than focusing on a specific muscle. This approach has commonly been used in elderly, stroke, and postoperative patients. ${ }^{21}$ The results of Yildiz et al. suggest that interventions should focus on enhancing basic functional mobility rather than on isolated muscle strengthening in order to improve FMS ${ }^{\mathrm{TM}}$ scores.

There were several limitations to this study. First, many of the studies did not include control groups, making the interpretation of the intervention group results difficult. Second, there was a large disparity in the age ranges of the participants. It is possible that age influences the degree of improvement in FMS ${ }^{\mathrm{TM}}$ scores following an intervention program. Third, this review included a wide variety of sports. It is possible that an intervention that was successful for athletes participating in one particular sport may not have the same results for athletes in another sport. Future studies should seek to determine what may constitute clinically significant improvements in $\mathrm{FMS}^{\mathrm{TM}}$ scores.

\section{CONCLUSION}

The results of this systematic review indicate that intervention programs can improve total $\mathrm{FMS}^{\mathrm{TM}}$ scores in "highrisk" athletes. Despite variations in the corrective exercises performed, the number of training sessions, and the length of the intervention program, all studies demonstrated an increase in the total FMS ${ }^{\mathrm{TM}}$ scores following program implementation in the athletes that participated.

\section{CONFLICTS OF INTEREST}

The authors have no conflicts of interest.

Submitted: August 10, 2021 CST, Accepted: October 13, 2021 CST 


\section{REFERENCES}

1. Narducci E, Waltz A, Gorski K, Leppla L, Donaldson $M$. The clinical utility of functional performance tests within one-year post-acl reconstruction: a systematic review. Int J Sports Phys Ther. 2011;6(4):333-342.

2. Brown MT. The ability of the functional movement screen in predicting injury rates in Divison I female athletes. University of Toledo. Published online 2011. h ttp://rave.ohiolink.edu/etdc/view?acc_num=toledo13 $\underline{02275741}$

3. Sheu Y, Chen LH, Hedegaard H. Sports- and recreation-related injury episodes in the united states, 2011-2014. Natl Health Stat Report. 2016;(99):1-12.

4. Moran RW, Schneiders AG, Mason J, Sullivan SJ. Do functional movement screen (FMS) composite scores predict subsequent injury? A systematic review with meta-analysis. Br J Sports Med.

2017;51(23):1661-1669. doi:10.1136/bjsports-2016-09 $\underline{6938}$

5. Chorba RS, Chorba DJ, Bouillon LE, Overmyer CA, Landis JA. Use of a functional movement screening tool to determine injury risk in female collegiate athletes. N Am J Sports Phys Ther. 2010;5(2):47-54.

6. Kiesel K, Plisky PJ, Voight ML. Can serious injury in professional football be predicted by a preseason functional movement screen? N Am J Sports Phys Ther. 2007;2(3):147-158.

7. Bardenett SM, Micca JJ, DeNoyelles JT, Miller SD, Jenk DT, Brooks GS. Functional movement screen normative values and validity in high school athletes: can the FMS ${ }^{\mathrm{TM}}$ be used as a predictor of injury? Int $J$ Sports Phys Ther. 2015;10(3):303-308.

8. Kiesel K, Plisky P, Butler R. Functional movement test scores improve following a standardized offseason intervention program in professional football players. Scand J Med Sci Sports. 2011;21(2):287-292. $\underline{\mathrm{d}}$ oi:10.1111/i.1600-0838.2009.01038.x

9. O’Connor FG, Deuster PA, Davis J, Pappas CG, Knapik JJ. Functional movement screening: predicting injuries in officer candidates. Med Sci Sports Exerc. 2011;43(12):2224-2230. doi:10.1249/MS $\underline{\text { S.0b013e318223522d }}$

10. Verstegen M, Falsone S, Orr R, Smith S. Suggestions from the field for return to sports participation following anterior cruciate ligament reconstruction: American football. J Orthop Sports Phys Ther. 2012;42(4):337-344. doi:10.2519/jospt.201 $\underline{2.4031}$
11. Song HS, Woo SS, So WY, Kim KJ, Lee J, Kim JY. Effects of 16-week functional movement screen training program on strength and flexibility of elite high school baseball players. J Exerc Rehabil. 2014;10(2):124-130. doi:10.12965/jer.140101

12. Bunn PDS, Rodrigues AI, Bezerra da Silva E. The association between the functional movement screen outcome and the incidence of musculoskeletal injuries: A systematic review with meta-analysis. Phys Ther Sport. 2019;35:146-158. doi:10.1016/j.pts p.2018.11.011

13. Moher D, Liberati A, Tetzlaff J, Altman DG, Prisma Group. Preferred reporting items for systematic reviews and meta-analyses: the PRISMA statement. PLoS Med. 2009;6(7):e1000097-e1000097. doi:10.137 1/journal.pmed.1000097

14. Downs SH, Black N. The feasibility of creating a checklist for the assessment of the methodological quality both of randomised and non-randomised studies of health care interventions. J Epidemiol Community Health. 1998;52(6):377-384. doi:10.1136/j ech.52.6.377

15. Wright JG, Swiontkowski MF, Heckman JD. Introducing levels of evidence to the journal. J Bone Joint Surg Am. 2003;85(1):1-3.

16. Bagherian S, Ghasempoor K, Rahnama N, Wikstrom EA. The effect of core stability training on functional movement patterns in college athletes. $J$ Sport Rehabil. 2019;28(5):444-449. doi:10.1123/jsr.20 $\underline{17-0107}$

17. Bodden JG, Needham RA, Chockalingam N. The effect of an intervention program on functional movement screen test scores in mixed martial arts athletes. J Strength Cond Res. 2015;29(1):219-225. do $\mathrm{i}: 10.1519 / \mathrm{ISC} .0 \mathrm{~b} 013 \mathrm{e} 3182 \mathrm{a} 480 \mathrm{bf}$

18. Klusemann MJ, Pyne DB, Fay TS, Drinkwater EJ. Online video-based resistance training improves the physical capacity of junior basketball athletes. $J$ Strength Cond Res. 2012;26(10):2677-2684. doi:10.151 9/ISC.0b013e318241b021

19. Laws A, Williams S, Wilson C. The effect of clinical pilates on functional movement in recreational runners. Int J Sports Med. 2017;38(10):776-780. doi:10.1055/s-0043-111893 
20. Sulowska I, Oleksy Ł, Mika A, Bylina D, Sołtan J. The influence of plantar short foot muscle exercises on foot posture and fundamental movement patterns in long-distance runners, a non-randomized, nonblinded clinical trial. PLoS One. 2016;11(6):e0157917. doi:10.1371/journal.pone.0157917

21. Yildiz S, Pinar S, Gelen E. Effects of 8-week functional vs. traditional training on athletic performance and functional movement on prepubertal tennis players. J Strength Cond Res. 2019;33(3):651-661. doi:10.1519/jsc.00000000000029 $\underline{56}$

22. Peate WF, Bates G, Lunda K, Francis S, Bellamy K. Core strength: a new model for injury prediction and prevention. J Occup Med Toxicol. 2007;2:3. doi:10.118 $\underline{6 / 1745-6673-2-3}$

23. Hopper A, Haff EE, Barley OR, Joyce C, Lloyd RS, Haff GG. Neuromuscular training improves movement competency and physical performance measures in 11-13-year-old female netball athletes. J Strength Cond Res. 2017;31(5):1165-1176. doi:10.1519/jsc.0000 000000001794
24. Yamato TP, Maher CG, Saragiotto BT, et al. Pilates for low back pain: complete republication of a cochrane review. Spine (Phila Pa 1976). 2016;41(12):1013-1021. doi:10.1097/brs.00000000000 $\underline{01398}$

25. Lange C, Unnithan VB, Larkam E, Latta PM. Maximizing the benefits of pilates-inspired exercise for learning functional motor skills. J Bodyw Mov Ther. 2000;4(2):99-108. doi:10.1054/jbmt.1999.0161

26. Boozer MH, Finch A, Waite LR. Investigation of the relationship between arch height and maximum pronation angle during running. Biomed Sci Instrum. 2002;38:203-207.

27. Irving DB, Cook JL, Young MA, Menz HB. Obesity and pronated foot type may increase the risk of chronic plantar heel pain: a matched case-control study. BMC Musculoskelet Disord. 2007;8:41. doi:10.11 86/1471-2474-8-41

28. Kernozek TW, Ricard MD. Foot placement angle and arch type: effect on rearfoot motion. Arch Phys Med Rehabil. 1990;71(12):988-991. 